\title{
Improving Organizational Citizenship Behavior through Job Satisfaction, Leader-Member Exchange, and Work-Life Balance
}

\author{
Heriyadi $^{\text {1*; Heru Kurnianto Tjahjono²; Meika Kurnia Puji Rahayu }}{ }^{3}$ \\ ${ }^{1-3}$ Department of Magister Management, Universitas Muhammadiyah Yogyakarta \\ Jln. Brawijaya, Yogyakarta 55183, Indonesia \\ 'heriyadi.pasca17@mail.umy.ac.id; ${ }^{2}$ herukurnianto@umy.ac.id; ${ }^{3}$ meika_kurnia@umy.ac.id
}

Received: $31^{\text {st }}$ December 2019/ Revised: $30^{\text {th }}$ March 2020/ Accepted: $6^{\text {th }}$ April 2020

How to Cite: Heriyadi, Tjahjono, H. K., \& Rahayu, M. K. P. (2020). Improving Organizational Citizenship Behavior through Job Satisfaction, Leader-Member Exchange, and Work-Life Balance. Binus Business Review, 11(2), 97-104. https:// doi.org/10.21512/bbr.v11i2.6193

\begin{abstract}
The research aimed to analyze the effect of leader-member exchange, work-life balance, and job satisfaction on Organizational Citizenship Behavior (OCB). The respondents were nursing staff at a hospital in Indonesia. The sample was 169 respondents, taken using a purposive sampling technique. Structural Equation Modeling (SEM) method was applied as the data analysis techniques with the application AMOS 22.0. Based on the results, the research finds that first, leader-member exchange and work-life balance have a positive and significant effect on job satisfaction and OCB. Second, job satisfaction affects OCB positively and significantly. Third, job satisfaction mediates the influence of leader-member exchange on OCB significantly. Fourth, job satisfaction also mediates the effect of work-life balance on OCB significantly. In conclusion, fostering OCB in hospitals is very important to produce better health service performance. The research shows that by increasing leader-member exchange, worklife balance, and job satisfaction, it can improve OCB. Overall, the research presents a significant contribution to the development of research in the field of human resource management and organizational behavior in the health sector in Indonesia.
\end{abstract}

Keywords: organizational citizenship behavior, job satisfaction, leader-member exchange, work-life balance

\section{INTRODUCTION}

A hospital is a vital object for people's lives by providing health services. Optimal service can be realized when organizational functions within the hospital run effectively. It should also be supported by human resources that are reliable, highly dedicated, and focused on the organization's interests. One factor that can encourage organizational effectiveness is organizational citizenship behavior (OCB). OCB is individual discretionary behavior and is not explicitly recognized formally. However, it can improve organizational functions to be more effective. OCB supports the social and psychological environment in which the performance of the task takes place (Organ, 1997).

The previous researcher shows that job satisfaction is a factor that drives the appearance of OCB (Tharikh, Ying, \& Saad, 2016). Job satisfaction is believed to have encouraged the emergence of positive employee attitudes to put the interests of the organization above the interests of individuals. It also encourages employees to do work with full responsibility even beyond what is expected by the organization. According to Robbins and Judge (2017), job satisfaction leading to OCB is the element of trust. Research in 18 countries shows that managers respond to OCB employees by showing trust in them. Also, employees who feel they have the support of their coworkers are more likely to engage in helpful behaviors than those who have antagonistic colleague relationships.

The research of OCB has been done extensively and has experienced interesting developments. Many 
researchers show that $\mathrm{OCB}$ can be influenced by organizational and individual environmental aspects (Tjahjono, Prasetyo, \& Palupi, 2018). OCB is also influenced by several factors, including the quality of leader-member exchange and work-life balance. Empirical studies suggest that the exchange of highquality leader-member exchange has a positive contribution to improving OCB. Leader-member exchange is an important element in promoting a mutually beneficial relationship between supervisors and subordinates, which ultimately motivates subordinates to perform OCB (Ibrahim, Ghani, Hashim, \& Amin, 2017). OCB is also affected by work-life balance. Empirical studies reveal that worklife balance can promote employees' involvement in OCB (Pradhan, Jena, \& Kumari, 2016). Work-life balance contributes to encouraging employees to show positive attitudes. It has become a crucial issue in working (Rao, 2017).

In addition to playing a role as a factor in driving OCB, leader-member exchange and work-life balance are also found to play an important role in encouraging job satisfaction. Several research results reveal that leader-member exchange has a positive and significant effect on job satisfaction ( $\mathrm{Li}, \mathrm{Zhu}, \&$ Park, 2018). The researchers also state that worklife balance has a positive impact on job satisfaction (Kaliannan, Perumal, \& Dorasamy, 2016).

The development of the leader-member exchange literature increases when researchers and business leaders begin to realize the impact of leader-member exchange on job outcomes such as job satisfaction, employee turnover, and performance (Bauer \& Erdogan, 2016). the higher the leadermember exchange is, the higher the job satisfaction of employees will be ( $\mathrm{Li}$ et al., 2018; Hall, Baker, Andrews, Hunt, \& Rapp, 2016). In addition, when leader-member exchange relationships are high, the subordinates also tend to be more satisfied with their leaders and reduce job stress (Probst, Jiang, \& Graso, 2016). This finding is in line with the results of another researcher that finds a relatively strong positive correlation between leader-member exchange and job satisfaction (Li et al., 2018). Thus, the first hypothesis of the research is as follows:

H1 : leader-member exchange has a positive effect on job satisfaction

Work-life balance is one of the factors that can encourage job satisfaction. If the employees can carry out the work and personal responsibilities in a balanced manner, they can reduce the occurrence of stress and job dissatisfaction. For this reason, the employees need time for community, family, hobbies, and others to achieve a healthy work-life balance (Arora \& Wagh, 2017). The workload of employees will have an impact on the perceived work-life balance and affect the level of their job satisfaction (Kaliannan et al., 2016). The second hypothesis is:
$\mathrm{H} 2$ : work-life balance has a positive effect on job satisfaction

According to Robbins and Judge (2017), the outcomes from job satisfaction specifically can be identified in three ways. Those are the increases in job performance, OCB, and customer satisfaction. Various researchers agree that job satisfaction is a positive driving factor in the emergence of OCB in the work environment (Pio \& Tampi, 2018; Tharikh et al., 2016). Hence, the third hypothesis is as follows:

\section{H3 : job satisfaction has a positive effect on OCB}

The leader-member exchange theory states that leaders develop different relationships with their subordinates and act differently with the people under them. Subordinates will fall into one of two groups. There is the in-group with high-quality relationships, or the out-group with low-quality relationships (Aamodt, 2016). Subordinates in the in-group with leaders who are willing to share valuable resources, such as time, information, and personal support, tend to do OCB with more enthusiasm compared to subordinates in the out-group. Thus, the effectiveness and willingness of subordinates to perform OCB are highly dependent on the effectiveness of leadership and the quality of the relationship between the two (Ibrahim, Ghani, \& Salleh, 2013). High-quality exchanges between supervisors and subordinates can increase the positive effect on employees in doing OCB (Kapil \& Rastogi, 2018). Therefore, the fourth hypothesis is:

\section{H4 : leader-member exchange has a positive effect on OCB}

The balance of work-life and social life has a significant impact on employee attitudes and organizational effectiveness. The previous research reveals a positive and significant relationship of worklife balance on OCB. Work-life balance can promote employees' involvement in OCB, which can benefit the organization through positive effectiveness. The high quality of work-life balance is important for the organization to continue to retain its best employees (Pradhan et al., 2016). The fifth hypothesis of the research is:

\section{H5 : work-life balance has a positive effect on OCB}

According to Liu, Lin, and Hu (2013), leaders can reduce their employees' unethical behavior by maintaining job satisfaction and social exchange with subordinates. Several researchers show the importance of job satisfaction in mediating leadermember exchange and work results. For example, job satisfaction acts as a mediator of the relationship between leader-member exchange and OCB (Ibrahim et al., 2013). Hence, the sixth hypothesis is as follows: 
H6 : job satisfaction mediates the effect of leader-member exchange on $\mathrm{OCB}$

Organizations must try to provide better working conditions to help their employees to have a better work-life balance. Therefore, organizations need to pay special attention to job satisfaction because it is not only an indicator of work-life balance but is also related to employees' OCB (Yu, Wang, \& Huang, 2018). Job satisfaction mediates the relationship between work interference with family and OCB (Yu et al., 2018). There is also an indirect relationship of work-life balance to OCB mediated by job satisfaction (Prasetio, Yuniarsih, \& Ahman, 2017). The seventh hypothesis is:

H7 : job satisfaction mediates the effect of work-life balance on $\mathrm{OCB}$

The purpose of this research is to determine the pattern of relationships between the leader-member exchange, work-life balance, job satisfaction, and OCB as seen in Figure 1. This research is conducted at a hospital. Health institutions are service-oriented institutions required to provide high-quality services. The high sensitivity of the community to health services has increased the need for the importance of OCB in hospitals. OCB in hospitals is necessary because each patient requires special care and positive behavior from medical personnel when handling their cases. OCB is believed to improve service efficiency, patient satisfaction, and hospital image and produce better organizational performance achievement (Kolade, Oluseye, \& A, 2014).

The researchers expect the research can be valuable information for human resources managers in hospitals in managing and developing human resources. So, they can improve health services to the community. The research can also be considered in making policies to enhance OCB in organizations, such as encouraging the creation of high-quality relationships between leaders and subordinates, offering work-life balance programs, improving job satisfaction, and creating a sense of belonging in the workplace.

\section{METHODS}

The research uses a purposive sampling technique. The sample is limited to people who are considered to provide the desired information. In this technique, the researcher also set specific criteria (Sekaran \& Bougie, 2016). The respondents are nursing staff at Regional General Hospital (Rumah Sakit Umum Daerah (RSUD)) in Muntilan Magelang District, Central Java, Indonesia. They have worked for at least one year. The employees with a minimum work duration of one year are considered to have enough experience to respond to the problems studied.

Structural Equation Modeling (SEM) requires at least five times a sample of the number of indicators used (Hair Jr, Black, Babin, \& Anderson, 2018). There are 33 indicators in the research, so the minimum number of samples needed is 165 samples $(33 \times 5)$. However, to reduce the response bias and to anticipate a sample dropping out, the researchers decide to increase the sample size to 175 respondents (10 more samples than the initial target) to ensure the desired number of respondents. Only 173 questionnaires are returned, and only 169 are eligible to be used. Meanwhile, the rest can not be used because the answers are incomplete.

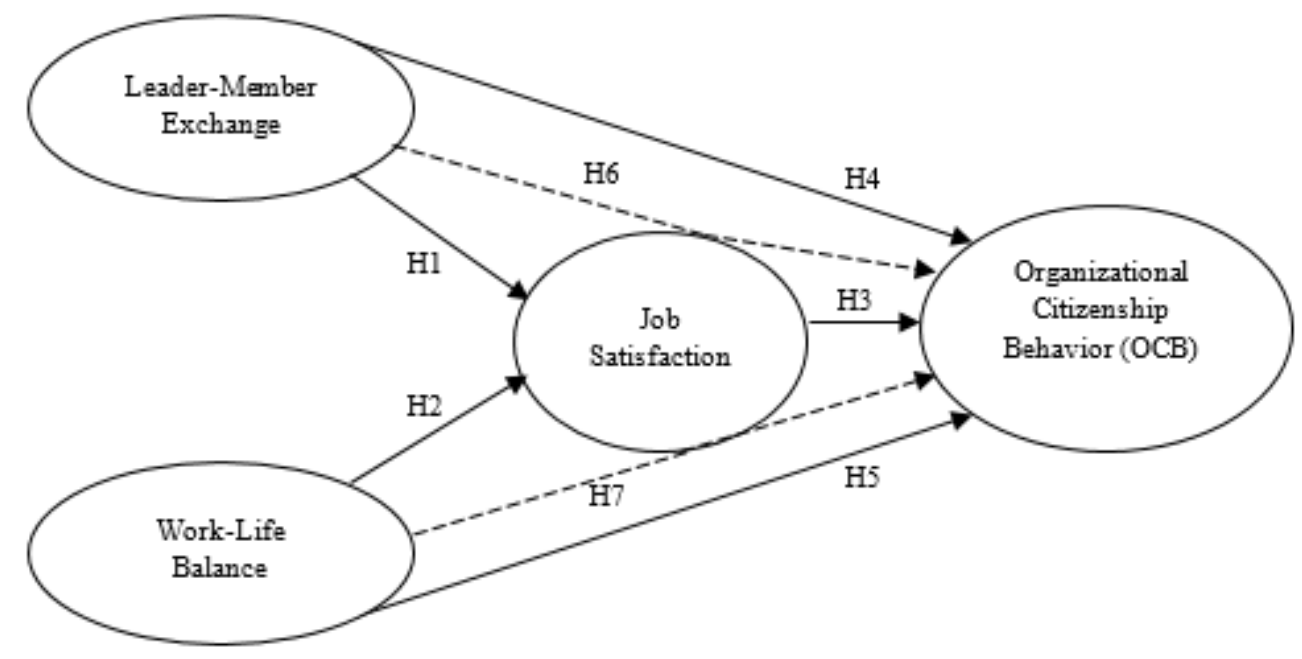

Figure 1 Conceptual Model 
Table 1 Demographic Data of the Respondents

\begin{tabular}{lcc}
\hline Category & Frequency & $\%$ \\
\hline Gender & & \\
Male & 22 & $13,02 \%$ \\
Female & 147 & $86,98 \%$ \\
Age & & \\
20 to 25 years & 7 & $4,14 \%$ \\
26 to 30 years & 25 & $14,79 \%$ \\
31 to 35 years & 57 & $33,73 \%$ \\
36 to 40 years & 36 & $21,30 \%$ \\
More than 40 years & 44 & $26,04 \%$ \\
Educational level & & \\
Diploma & 126 & $74,56 \%$ \\
Bachelor's degree & 43 & $25,44 \%$ \\
Marital status & & \\
Married & 151 & $89,35 \%$ \\
Single & 18 & $10,65 \%$ \\
Experience & & \\
1 to 3 years & 11 & $6,51 \%$ \\
4 to 6 years & 27 & $15,98 \%$ \\
7 to 9 years & 55 & $32,54 \%$ \\
Ten years and over & 76 & $44,97 \%$ \\
\hline
\end{tabular}

As shown in Table 1, the majority of respondents are women $(86,98 \%)$. It is very reasonable because women dominate the nursing staff in Indonesia. Considering the age, the majority of respondents are 31 to 35 years $(33,73 \%)$. In general, it is relatively productive because it is dominated by employees under the age of 40 . Then, a diploma $(74,56 \%)$ is the highest at the educational level, and most of them are married $(89,35 \%)$. In terms of experience, most of the employees have worked for more than 10 years $(44,97 \%)$. The data show that they are a very experienced workforce.

All variables in the research are measured using a five-point Likert-scale $(1=$ strongly disagree; $2=$ disagree; $3=$ neutral; $4=$ agree; and $5=$ strongly agree). OCB is measured using 16 items developed by Lee and Allen (2002). Similarly, the leader-member exchange uses the LMX-7 instrument by Graen and Uhl-Bien (1995). Then, work-life balance is measured using four items by Brough et al. (2014). Job satisfaction has six items adopted from the Job Satisfaction Index by Schriesheim and Tsui (1980).

The data analysis technique uses the SEM through the AMOS 22.0 with the maximum likelihood estimation method. Besides, the researchers also use the Sobel test to determine the level of significance of the role of mediation.

\section{RESULTS AND DISCUSSIONS}

The validity test in the research is the
Confirmatory Factor Analysis (CFA). The indicator is valid if it has a standard loading factor of more than 0,5 and p-value of less than 0,05. Based on AMOS 22.0 output, all exogenous construct indicators are valid because they have a standard loading factor value of more than 0,5 and p-value of less than 0,05. However, in the endogenous construct, there is an invalid indicator, which is OCB4. It has a loading factor value below 0,5 . In the next analysis, this OCB4 indicator will be removed to achieve validity standards. The results are in Tables 2 and 3.

Table 2 Exogenous Construct Validity Test

\begin{tabular}{lcccc}
\hline Indikator & $\begin{array}{c}\text { Critical } \\
\text { Ratio }\end{array}$ & Prob. & $\begin{array}{c}\text { Loading } \\
\text { Factor }\end{array}$ & Decision \\
\hline LMX1 & & & 0,611 & Valid \\
LMX2 & 7,327 & $* * *$ & 0,717 & Valid \\
LMX3 & 7,185 & $* * *$ & 0,697 & Valid \\
LMX4 & 7,850 & $* * *$ & 0,796 & Valid \\
LMX5 & 7,052 & $* * *$ & 0,679 & Valid \\
LMX6 & 6,556 & $* * *$ & 0,616 & Valid \\
LMX7 & 6,993 & $* * *$ & 0,672 & Valid \\
WLB1 & & & 0,723 & Valid \\
WLB2 & 7,613 & $* * *$ & 0,726 & Valid \\
WLB3 & 6,990 & $* * *$ & 0,643 & Valid \\
WLB4 & 7,176 & $* * *$ & 0,665 & Valid \\
\hline
\end{tabular}

Note: Leader-Member Exchange (LMX) and Work-Life Balance (WLB).

Table 3 Endogenous Construct Validity Test

\begin{tabular}{lcccc}
\hline Indicator & $\begin{array}{c}\text { Critical } \\
\text { Ratio }\end{array}$ & Prob. & $\begin{array}{c}\text { Loading } \\
\text { Factor }\end{array}$ & Decision \\
\hline JS1 & 7,809 & $* * *$ & 0,692 & Valid \\
JS2 & 8,075 & $* * *$ & 0,701 & Valid \\
JS3 & 7,357 & $* * *$ & 0,633 & Valid \\
JS4 & 8,033 & $* * *$ & 0,697 & Valid \\
JS5 & 8,039 & $* * *$ & 0,698 & Valid \\
JS6 & & & 0,731 & Valid \\
OCB1 & 9,381 & $* * *$ & 0,718 & Valid \\
OCB2 & 9,109 & $* * *$ & 0,698 & Valid \\
OCB3 & 5,543 & $* * *$ & 0,433 & Invalid \\
OCB4 & 9,221 & $* * *$ & 0,706 & Valid \\
OCB5 & 9,411 & $* * *$ & 0,720 & Valid \\
OCB6 & 9,700 & $* * *$ & 0,740 & Valid \\
OCB7 & 9,648 & $* * *$ & 0,737 & Valid \\
OCB8 & 10,025 & $* * *$ & 0,764 & Valid \\
OCB9 & 10,550 & $* * *$ & 0,801 & Valid \\
OCB10 & 10,526 & $* * *$ & 0,799 & Valid \\
OCB11 & 10,600 & $* * *$ & 0,804 & Valid \\
OCB12 & 9,060 & $* * *$ & 0,694 & Valid \\
OCB13 & 9,884 & $* * *$ & 0,754 & Valid \\
OCB14 & 9,882 & $* * *$ & 0,753 & Valid \\
OCB15 & 10,787 & $* * *$ & 0,817 & Valid \\
OCB16 & & & & \\
\hline
\end{tabular}

Note: Job Satisfaction (JS) and Organizational Citizenship Behavior (OCB). 
Moreover, a reliability test is conducted. All variables have to construct reliability values of more than 0,7 . So, it means that the constructs are reliable. The result is in Table 4.

Table 4 Reliability Statistics

\begin{tabular}{lc}
\hline Variable & Critical Ratio \\
\hline Leader-Member Exchange & 0,9 \\
Work-Life Balance & 0,8 \\
Job Satisfaction & 0,8 \\
Organizational Citizenship Behavior & 0,9 \\
\hline
\end{tabular}

Table 5 CFA Full Model Testing Results

\begin{tabular}{lccc}
\hline Goodness of Fit Test & Cut off Value & Results & Decision \\
\hline $\begin{array}{l}\text { Chi-Square (df =458) } \\
\text { Significance }\end{array}$ & $<508,893$ & 515,919 & Unfit \\
$\begin{array}{l}\text { Probability } \\
\text { CMIN/DF }\end{array}$ & $\geq 0,05$ & 0,031 & Unfit \\
GFI & $\leq 2$ & 1,126 & Good Fit \\
& $\geq 0,90$ & 0,845 & $\begin{array}{c}\text { Marginal } \\
\text { AGFI }\end{array}$ \\
& $\geq 0,90$ & 0,822 & $\begin{array}{c}\text { Marginal } \\
\text { TLI }\end{array}$ \\
CFI & $\geq 0,95$ & 0,978 & $\begin{array}{c}\text { Good Fit } \\
\text { RMSEA }\end{array}$ \\
& $\geq 0,95$ & 0,979 & Good Fit \\
& $\leq 0,08$ & 0,028 & Good Fit \\
\hline
\end{tabular}

Note: the minimum sample discrepancy function is divided into degree of freedom (CMIN/DF), Goodness of Fit Index (GFI), Adjusted Goodness of Fit Index (AGFI), TuckerLewis index (TLI), Comparative Fit Index (CFI), and the Root Mean Square Error of Approximation (RMSEA).

In Table 5, CFA test results show that overall, the research model is an acceptable fit model. Even though the chi-square value is 515,919 and the significance probability is $0,031(<0,05)$, but values of DF $(458)$, CMIN/DF $(1,126)$, TLI $(0,978)$, CFI $(0,979)$, and RMSEA $(0,028)$ have met the recommended criteria. Meanwhile, the values of GFI $(0,845)$ and AGFI $(0,822)$ are slightly below the recommended value. Those are categorized as a marginal fit. According to Hair Jr et al. (2018), the use of three to four indexes is sufficient to provide adequate model compatibility evidence. However, the researchers must report at least one incremental fit index (CFI or TLI) and one absolute fit index (GFI or RMSEA), chi-square value $\mathrm{X} 2$, and related degrees of freedom.

Table 6 shows the results of the hypothesis test. $\mathrm{H} 1$ test results show that leader-member exchange has a positive and significant effect on job satisfaction. Thus, H1 is accepted. The finding explains that a higher quality of leader-member exchange will have an impact on increasing job satisfaction. The leader has a positive role in employee job satisfaction. Leader-member exchange is positively related to job satisfaction because the quality of social exchange relationships with supervisors is part of work experience (Tjahjono et al., 2018). Thus, when the leader-member exchange relationship is high, the overall job experience will also be more satisfying (Zhou \& Wang, 2016). The result is also in line with the results of other researchers finding a strong positive correlation between leader-member exchange and job satisfaction (Kim \& Yi, 2019; Li et al., 2018).

Table 6 The Results of Hypothesis Testing

\begin{tabular}{|c|c|c|c|c|c|c|}
\hline & \multicolumn{3}{|c|}{ Hypothesis } & \multirow{2}{*}{$\begin{array}{l}\text { C.R. } \\
5,132\end{array}$} & \multirow{2}{*}{$\begin{array}{c}\text { Prob. } \\
* * *\end{array}$} & \multirow{2}{*}{$\begin{array}{c}\text { Decision } \\
\text { Sig. }\end{array}$} \\
\hline H1 & LMX & $\rightarrow$ & JS & & & \\
\hline $\mathrm{H} 2$ & WLB & $\rightarrow$ & JS & 4,364 & $* * *$ & Sig. \\
\hline $\mathrm{H} 3$ & JS & $\rightarrow$ & OCB & 4,032 & $* * *$ & Sig. \\
\hline $\mathrm{H} 4$ & LMX & $\rightarrow$ & OCB & 2,307 & 0,021 & Sig. \\
\hline $\mathrm{H} 5$ & WLB & $\rightarrow$ & OCB & 2,142 & 0,032 & Sig. \\
\hline
\end{tabular}

* Notes: it is significant if Prob. is $\leq 0,05$, or Critical Ratio (C.R.) is $\geq 1,96$. Leader-Member Exchange (LMX), Work-Life Balance (WLB), Job Satisfaction (JS), and Organizational Citizenship Behavior (OCB).

The result of $\mathrm{H} 2$ shows that work-life balance affects job satisfaction positively and significantly. So, $\mathrm{H} 2$ is accepted. This finding explains that the higher the work-life balance is, the higher the job satisfaction will be. The literature notes that work-life balance is one of the important antecedents of job satisfaction. Employees who suffer from conflicts between work and non-work issues have lower levels of job satisfaction (Fayyazi \& Aslani, 2015). The work-life balance determines how much time is available to balance the demands of family and work (Soomro, Breitenecker, \& Shah, 2018). Achieving a good worklife balance will make employees feel they have control over their work and non-work life. So, it will increase job satisfaction. These results are in line with other researchers suggesting that work-life balance has a positive influence on job satisfaction (Fiernaningsih, Nimran, Raharjo, \& Arifin, 2019; Pangemanan, Pio, \& Tumbel, 2017; Ronda, Ollo-López, \& Goñi-Legaz, 2016).

In $\mathrm{H} 3$, the result shows that job satisfaction has a positive and significant effect on OCB. So, H3 is accepted. The higher job satisfaction is, the higher the OCB will be. According to Robbins and Judge (2017), job satisfaction is positively related to OCB. It is based on social exchange theory and the principle of reciprocity. OCB behavior is one of the ways to rewarding organizations that have provided a pleasant work environment. The result is in line with previous researchers agreeing that job satisfaction is a positive driving factor in the OCB in the work environment (Pio \& Tampi, 2018; Sawitri, Suswati, \& Huda, 2016; 
Tharikh et al., 2016).

For H4, the result shows a positive and significant effect of leader-member exchange on OCB. A higher quality of the relationship between superiors and subordinates will impact the increase in OCB. The main focus of the leader-member exchange is on the unique relationship between a leader and a subordinate (Day \& Miscenko, 2016). Leaders develop different relationships with subordinates. These results are in line with El Shaer (2019), Estiri, Amiri, Khajeheian, and Rayej (2018), and Hashim (2016) presenting the positive relationship between leader-member exchange and OCB.

In $\mathrm{H} 5$, work-life balance has a positive and significant effect on OCB. The higher the work-life balance of the employees is, the higher the OCB will be. Work-life balance has become a significant problem at work because it contributes to encouraging employees to show a positive attitude (Rao, 2017). Work-life balance can increase employees' involvement in OCB. So, it can benefit the organization through positive effectiveness. The result is supported by other research suggesting work-life balance has a positive effect on increasing OCB (Amar, 2019; Pradhan et al., 2016; Raharjo, Fiernaningsih, Nimran, \& Arifin, 2019).

Table 7 Direct, Indirect, and Total Effect

\begin{tabular}{lccc}
\hline & $\begin{array}{c}\text { Direct } \\
\text { Effects }\end{array}$ & $\begin{array}{c}\text { Indirect } \\
\text { Effects }\end{array}$ & $\begin{array}{c}\text { Total } \\
\text { Effects }\end{array}$ \\
\hline - LMX on JS & 0,512 & - & 0,512 \\
- WLB on JS & 0,408 & - & 0,408 \\
- JS on OCB & 0,499 & - & 0,499 \\
- LMX on OCB & 0,214 & - & \\
- LMX on OCB & - & 0,255 & 0,469 \\
through JS & - & - & \\
- WLB on OCB & 0,191 & 0,204 & 0,395 \\
- WLB on OCB & - & & \\
through JS & & & \\
\hline
\end{tabular}

Note: leader-member exchange (LMX), work-life balance (WLB), job satisfaction (JS), and Organizational Citizenship Behavior (OCB).

In Table 7, the mediation test output through AMOS 22.0 shows that the indirect effect of leadermember exchange on OCB through job satisfaction $(0,255)$ is greater than the direct effect of leadermember exchange on $\operatorname{OCB}(0,214)$. This result is also confirmed by the Sobel test with t-value of 3,1786 $(>1,96)$ and $p$-value of $0,0015(<0,05)$. Thus, it can be concluded that $\mathrm{H} 6$ is accepted. Job satisfaction mediates the influence of leader-member exchange on OCB significantly. Employees who have good leader-member exchange quality, tend to feel comfortable working with superiors who want to share information, trust, and respect them. These positive feelings encourage the growth of job satisfaction in the employees and become a way for OCB to emerge in the office. The better the quality of the relationship between employee and supervisor is, the higher the job satisfaction will be. Ultimately, it can improve OCB in the employees. The results are in line with previous researchers showing that job satisfaction acts as a mediator of the relationship between leader-member exchange and OCB (Ibrahim et al., 2013).

Next, the mediation test output through AMOS 22.0 reveals that the indirect effect of work-life balance on OCB through job satisfaction $(0,204)$ is greater than the direct effect of work-life balance on OCB $(0,191)$. This result is also strengthened by the Sobel test with t-value of 2,9599 $(>1,96)$ and $\mathrm{p}$-value of 0,0031 $(<0,05)$. Thus, it means that $\mathrm{H} 7$ is accepted. There is a significant effect of work-life balance on OCB through job satisfaction. Job satisfaction is not only an indicator of work-life balance, but it is also related to OCB (Yu et al., 2018). The better the work-life balance achievement is, the higher the job satisfaction of employees will be, and the more the employees involve in OCB. The results of are supported Prasetio et al. (2017) and Yu et al. (2018) mentioning indirect relationship from the effect of work-life balance on OCB mediated by job satisfaction.

\section{CONCLUSIONS}

The research aims to analyze the effect of leader-member exchange, work-life balance, and job satisfaction on OCB. Based on the results of data analysis through AMOS 22.0 and Sobel test, there are seven conclusions. First, the leader-member exchange has a positive and significant effect on job satisfaction. Second, work-life balance affects job satisfaction positively and significantly. Third, job satisfaction has a positive and significant impact on OCB. Fourth, there is a positive and significant effect of leadermember exchange on OCB. Fifth, work-life balance influences OCB positively and significantly. Sixth, job satisfaction mediates the influence of leader-member exchange on OCB significantly. Last, there is a significant effect of work-life balance on OCB through job satisfaction.

The research findings show that leader-member exchange, work-life balance, and job satisfaction have an essential role in improving OCB. The results can be valuable information for hospital management in making policies that can encourage OCB improvement. First, it is improving the quality of relationships between supervisors and subordinates. Supervisors need to ask the subordinates' opinions in making strategic decisions related to subordinates. Besides, subordinates also need to be given adequate trust in carrying out their duties. It is to foster mutual respect and trust in each other. Second, it is encouraging the achievement of better work-life balance. For example, it can be done by involving them in preparing work schedules, providing ease of permission for employees who have urgent needs, encouraging 
employees to take annual leave, and providing nonformal activities that can reduce work stress such as outbound, family gathering, and spiritual activities. Third, it is encouraging the increase in job satisfaction through equitable management for all employees. For example, organizations provide equal promotion opportunities and fair compensation.

The research has limitations that need to be considered for further research. First, the research object is only limited to one hospital, so these results cannot be generalized. The second limitation relates to the use of questionnaires for data collection (bias and sampling errors). Third, the research only focuses on the leader-member exchange, work-life balance, and job satisfaction as the factors that influence the emergence of OCB in nursing staff. Future research is expected to analyze other factors, such as organizational commitment, transformational leadership, decision authority, and other factors as an antecedent of OCB.

\section{REFERENCES}

Aamodt, M. G. (2016). Industrial/organizational psychology: An applied approach $\left(8^{\text {th }} \mathrm{ed}\right.$.). Boston, MA: Cengage Learning.

Amar, S. (2019). The effect of emotional intelligence and work life balance on organizational citizenship behavior with career development as mediating variable (A case study at PT. Bank Pembangunan Daerah (BPD) head office and main branch, Padang). In Third Padang International Conference On Economics Education, Economics, Business and Management, Accounting and Entrepreneurship (PICEEBA 2019).

Arora, C., \& Wagh, R. (2017). Importance of work-life balance. International Journal of New Technology and Research, 3(6), 23-25.

Bauer, T. N, \& Erdogan, B. (2016). Leader-Member Exchange (LMX) theory: An introduction and overview. In T. N. Bauer \& B. Erdogan (Eds.), The Oxford handbook of Leader-Member Exchange (pp. 3-9). New York: Oxford University Press.

Brough, P., Timms, C., O’Driscoll, M. P., Kalliath, T., Siu, O. L., Sit, C., \& Lo, D. (2014). Work-life balance: A longitudinal evaluation of a new measure across Australia and New Zealand workers. The International Journal of Human Resource Management, 25(19), 2724-2744.

Day, D. V., \& Miscenko, D. (2016). Leader-Member Exchange (LMX): Construct evolution, contributions, and future prospects for advancing leadership theory. In T. N. Bauer \& B. Erdogan (Eds.), The Oxford handbook of Leader-Member Exchange (pp. 9-28). New York: Oxford University Press.

El Shaer, T. (2019). The relationship between leadermember exchange, organisational citizenship behaviour, and organisational commitment among UNRWA health staff in the Gaza governorates. The Lancet, 393, S46.

Estiri, M., Amiri, N. S., Khajeheian, D., \& Rayej, H. (2018).
Leader-member exchange and organizational citizenship behavior in hospitality industry: A study on effect of gender. Eurasian Business Review, 8(3), 267-284.

Fayyazi, M., \& Aslani, F. (2015). The impact of work-life balance on employees' job satisfaction and turnover intention; The moderating role of continuance commitment. International Letters of Social and Humanistic Sciences, 51, 33-41.

Fiernaningsih, N., Nimran, U., Raharjo, K., \& Arifin, Z. (2019). The role of work-life balance, organizational pride, and job satisfaction on organizational citizenship behaviour: Case study on hospitality employees in Indonesia. International Journal of Innovation, Creativity and Change, 8(4), 73-94.

Graen, G. B., \& Uhl-Bien, M. (1995). Relationship-based approach to leadership: Development of LeaderMember Exchange (LMX) theory of leadership over 25 years: Applying a multi-level multi-domain perspective. Leadership Quarterly, 6(2), 219-247.

Hair Jr., J. F., Black, W. C., Babin, B. J., \& Anderson, R. E. (2018). Multivariate data analysis ( $8^{\text {th }} \mathrm{ed}$.). London, United Kingdom: Cengage Learning EMEA.

Hashim, N. H. (2016). The impact of leader-member exchange on organizational citizenship behaviour readiness among local government employees in southern region of Malaysia. In Proceedings of the International Social Sciences and Tourism Research Conference (pp. 121-133).

Ibrahim, R. M., Ghani, M. A., Hashim, N. H., \& Amin, A. (2017). Does leader-member exchange impact on organizational citizenship behaviour readiness? Evidence from state government agency. International Review of Management and Marketing, 7(1), 216-221.

Ibrahim, R. M., Ghani, M. A., \& Salleh, A. M. M. (2013). Elevating organizational citizenship behavior among local government employees: The mediating role of job satisfaction. Asian Social Science, 9(13), 92-104.

Kaliannan, M., Perumal, K., \& Dorasamy, M. (2016). Developing a work-life balance model towards improving job satisfaction among medical doctors across different generations. The Journal of Developing Areas, 50(5), 343-351.

Kapil, K., \& Rastogi, R. (2018). Promoting organizational citizenship behaviour: The roles of leader-member exchange and organizational job embeddedness. South Asian Journal of Human Resources Management, 5(1), 56-75.

Kim, M. H., \& Yi, Y. J. (2019). Impact of leader-memberexchange and team-member-exchange on nurses' job satisfaction and turnover intention. International Nursing Review, 66(2), 242-249.

Kolade, O. J, Oluseye, O. O., \& A. O. O. (2014). Organizational citizenship behaviour, hospital corporate image and performance. Journal of Competitiveness, 6(1), 36-49.

Lee, K., \& Allen, N. J. (2002). Organizational citizenship behavior and workplace deviance: The role of affect and cognitions. Journal of Applied Psychology, 87(1), 131-142. 
Li, L., Zhu, Y., \& Park, C. (2018). Leader-member exchange, sales performance, job satisfaction, and organizational commitment affect turnover intention. Social Behavior and Personality: An International Journal, 46(11), 1909-1922.

Hall, K. K. L, Baker, T. L., Andrews, M. C., Hunt, T. G., \& Rapp, A. A. (2016). The importance of product/ service quality for frontline marketing employee outcomes: The moderating effect of Leader-Member Exchange (LMX). Journal of Marketing Theory and Practice, 24(1), 23-41.

Liu, S., Lin, X., \& Hu, W. (2013). How followers' unethical behavior is triggered by leader-member exchange: The mediating effect of job satisfaction. Social Behavior and Personality: An International Journal, 41(3), 357-366.

Organ, D. W. (1997). Organizational citizenship behavior: It's construct clean-up time. Human Performance, 10(2), 85-97.

Pangemanan, F. L., Pio, R. J., \& Tumbel, T. M. (2017). Pengaruh work-life balance dan burnout terhadap kepuasan kerja. Jurnal Administrasi Bisnis, 5(003), $1-8$.

Pio, R. J., \& Tampi, J. R. E. (2018). The influence of spiritual leadership on quality of work life, job satisfaction and organizational citizenship behavior. International Journal of Law and Management, 60(2), 757-767.

Pradhan, R. K., Jena, L. K., \& Kumari, I. G. (2016). Effect of work-life balance on organizational citizenship behaviour: Role of organizational commitment. Global Business Review, 17(3_suppl), 15S-29S.

Prasetio, A. P., Yuniarsih, T., \& Ahman, E. (2017). Analisis peran mediasi kepuasan kerja dan komitmen organisasi dalam hubungan work-life balance dan organizational citizenship behavior pada karyawan hotel di Bandung. In Maranatha Economics and Business Conference (MEBC) (pp. 1-22).

Probst, T. M., Jiang, L., \& Graso, M. (2016). Leadermember exchange: Moderating the health and safety outcomes of job insecurity. Journal of Safety Research, 56(February), 47-56.

Raharjo, K., Fiernaningsih, N., Nimran, U., \& Arifin, Z. (2019). Impact of work-life balance and organisational citizenship behaviour on intention to leave. International Journal of Innovation, Creativity and Change, 8(4), 95-113.

Rao, I. (2017). Work-life balance for sustainable human development: Cultural intelligence as enabler. Journal of Human Behavior in the Social Environment, 27(7), 706-713.

Robbins, S. P., \& Judge, T. A. (2017). Organizational behavior global edition (1 $7^{\text {th }}$ ed.). Boston: Pearson.

Ronda, L., Ollo-López, A., \& Goñi-Legaz, S. (2016). Family-friendly practices, high-performance work practices and work-family balance? Management Research: The Journal of the Iberoamerican Academy of Management, 14(1), 2-23.

Sawitri, D., Suswati, E., \& Huda, K. (2016). The impact of job satisfaction, organization commitment, Organization Citizenship Behavior (OCB) on employees' performance. International Journal of Organizational Innovation, 9(2), 24-45.

Schriesheim, C., \& Tsui, A. S. (1980). Development and validation of a short satisfaction instrument for use in survey feedback interventions. In Western Academy of Management Meeting (Vol. 1980, pp. 115-17).

Sekaran, U., \& Bougie, R. (2016). Research methods for business: A skill-building approach ( $\left.7^{\text {th }} \mathrm{ed}\right)$. Chichester, West Sussex, United Kingdom: John Wiley \& Sons.

Soomro, A. A., Breitenecker, R. J., \& Shah, S. A. M. (2018). Relation of work-life balance, work-family conflict, and family-work conflict with the employee performance-moderating role of job satisfaction. South Asian Journal of Business Studies, 7(1), 129146.

Tharikh, S. M., Ying, C. Y., \& Saad, Z. M. (2016). Managing job attitudes: The roles of job satisfaction and organizational commitment on organizational citizenship behaviors. Procedia Economics and Finance, 35, 604-611.

Tjahjono, H. K., Prasetyo, F., \& Palupi, M. (2018). Kepemimpinan transformasional pada organizational citizenship behavior dan komitmen afektif. Jurnal Manajemen dan Pemasaran Jasa, 11(2), 217-232.

Yu, K., Wang, Z., \& Huang, Y. (2018). Work-family conflict and organizational citizenship behavior: The role of job satisfaction and decision authority. Frontiers of Business Research in China, 12(1), 1-13.

Zhou, L., \& Wang, M. (2016). Leader-member exchange and newcomer adjustment. In T. N. Bauer \& B. Erdogan (Eds.), The Oxford handbook of leadermember exchange. New York: Oxford University Press. 